DOI: https://doi.org/10.15407/techned2018.04 $=\underline{033}$

\title{
NUMERICAL SIMULATION OF ELECTROMAGNETIC AND THERMAL FIELDS IN INDUCTION CHANNEL FURNACES WITH DEFECTS OF LINING
}

Journal

Publisher

ISSN

Issue

Pages
Tekhnichna elektrodynamika

Institute of Electrodynamics National Academy of Science of Ukraine 1607-7970 (print), 2218-1903 (online)

No 4, 2018 (July/August)

$33-36$

\section{Author}

\section{M.A. Shcherba*}

Institute of Electrodynamics National Academy of Sciences of Ukraine,

pr. Peremohy, 56, Kyiv, 03057, Ukraine,

e-mail:m.shcherba@gmail.com

* ORCID ID : http://orcid.org/0000-0001-6616-4567

\section{Abstract}

The numerical experiments and analysis of inhomogeneous distribution of electromagnetic and thermal fields in induction channel furnaces with various defects of their thermal insulation (lining) are carried out using finite element method and multi-physical modeling approaches. The problem is formulated in a nonlinear definition with strong mutual relations of subproblems for complex three-dimensional geometry. By the example of a furnace for melting of oxygen-free copper in the presence of leakage of the metal melt into furnace lining, the dependence of the temperature changes over the surface of the furnace body on the depth of penetration of the melt and its volume is determined. It is studied the changes in the temperature distribution 
inside of thermal insulation as it degrades, i.e. when each of the four layers of material is reached by melt. The emergency configurations of the melt leakage, which require the furnace to be shut down and replaced are determined, and the analysis of the existing situations observed on the casting lines at industrial plants is carried out. The application of the proposed calculation technique allows to control the state of induction channel furnaces and develop the recommendations for increasing their resource. References 12, figures 3.

Key words: electromagnetic field, induction heating, numerical simulation, interrelated processes, copper melting, thermal insulation defects.

Received: 02.03 .2018

Accepted: 15.03.2018

Published:

\section{References}

1. Podoltsev O.D., Kucheryava I.N. Multiphysical modeling of electrical devices. Tekhnichna Elektrodynamika . 2015. No 2. Pp. 11-19. (Rus)

2. Jian-Ming Jin The finite element method in electromagnetics. John Wiley \& Sons, 2015. 800 p.

3. Gleim T., Bettina S., Detlef K. Nonlinear thermo-electromagnetic analysis of inductive heating processes. Archive of Applied Mechanics. 2015. Vol. 85.8. Pp. 1055-1073.

4. Zolotarev V.M., Shcherba M.A., Zolotarev V.V., Belyanin R.V. Three-dimensional modeling of electromagnetic and thermal processes of induction melting of copper template with accounting of installation elements design. Tekhnichna Elektrodynamika. 2017. No 3. Pp. 13-21. DOI:

oi.org/10.15407/techned2017.03.013 https://d 
(Rus)

5. Yoav H., Kochavi E., Levy A. Inductive heating with a stepped diameter crucible. Applied Thermal Engineering.

2016. Vol. 102. Pp. 149-157.

6. Shcherba A.A., Podoltsev O.D., Kucheriava I.M., Ushakov V.I. Computer modeling of electrothermal processes and thermo-mechanical stress at induction heating of moving copper ingots. Tekhnichna Elektrodynamika. 2013. No 2. Pp. 10-18. (Rus)

7. Stegmueller M.J.R., Schindele P., Grant R.J. Inductive heating effects on friction surfacing of stainless steel onto an aluminum substrate. Journal of Materials Processing Technology. 2015. Vol. 216. Pp. 430-439.

8. Lucía O., Maussion P., Dede E.J. Induction heating technology and its applications: past developments, current technology, and future challenges. IEEE Trans. on Industrial Electronics . 2014. Vol. 61.5. Pp. 2509-2520.

9. Shcherba M.A. Three-dimensional modeling of electromagnetic and temperature fields in the inductor of channel-type furnace for copper heating. IEEE Conf. on Electrical and Computer Engineering (UKRCON), Kiev. 2017. Pp. 427-431.

10. Shcherba M.A. Coupled electromagnetic and thermal processes in thermal insulation of induction channel furnaces during changes of its defects configuration. Tekhnichna Elektrodynamika .2018.

No 2. Pp. 17 - 24. DOI:

https://doi.org/10.15407/techned2018.02.017

11. Landau L.D., Lifshyts E.M. Electrodynamics of continuums, Theor. Physics, vol. VIII. Moscow: Fizmatlit, 2003. 632 p. (Rus)

12. Comsol Multiphysics, https://www.comsol.com/ . Comsol Inc., Burlington, MA, USA, 2018. 